\title{
A EDUCAÇÃO PIAUIENSE EM TEMPOS DE FUNDEF: ENTRE AS PROMESSAS E AS INOVAÇÕES
}

\author{
PIAUÍ EDUCATION IN TIMES OF FUNDEF: \\ BETWEEN THE PROMISES AND INNOVATIONS
}

\author{
Cláudia Cristina da Silva Fontineles ${ }^{1}$ \\ Marcelo de Sousa Neto ${ }^{2}$
}

\begin{abstract}
Resumo: O texto discute a história da educação no Piauí entre os anos de 1995 e 2000 por ser muito importante para compreender a educação brasileira contemporânea e sua relação com as políticas públicas em nosso estado, tendo sido um período marcado pela elaboração e implantação do FUNDEF. O texto analisa a história da educação piauiense durante a década de 1990, em especial em relação à situação do atendimento no ensino público da rede estadual e à valorização do magistério (remuneração e condições de trabalho), procurando entender como o FUNDEF interferiu nos caminhos da educação escolar piauiense desde então. Para tanto, foi utilizada como metodologia, além da revisão bibliográfica acerca do tema, a análise de fontes documentais oficiais (leis e prestações de contas ao Tribunal de Contas do Estado e os índices oficiais de matrículas) e a comparação com o que era informado, no período, nos periódicos de circulação local. Os principais interlocutores teóricos do texto são Eneida Shiroma e Silker Weber, no que concerne às políticas públicas, e Francis Boakari e R. Rocha, no que se refere ao atendimento escolar no Piauí.
\end{abstract}

Palavras-chave: Educação. Políticas Públicas. História. Piauí.

\begin{abstract}
The text discusses the history of education in Piauí between the years 1995 and 2000 to be very important for understanding the contemporary Brazilian education and its relation to public policy in our state, and was a period marked by the development and deployment of FUNDEF. The text examines the history of education piauiense during the 1990s, particularly in relation to the situation in the care of the state public education and appreciation of teachers (pay and working conditions), focusing on how FUNDEF interfere in the ways of school education piauiense since. Therefore, it was used as a methodology, in addition to literature review on the topic, analysis of official documentary sources (laws and accounts to the Court of Auditors and the State official enrollment rates) and compared to what was reported in period, the local circulation periodicals. The main theoretical text interlocutors are Eneida Shiroma and Silker Weber, with respect to public policy, and Francis R. and Boakari Rocha, in relation to school attendance in Piauí.
\end{abstract}

Keywords: Education. Public Policy. History. Piauí.

\footnotetext{
${ }^{1}$ Doutora em História pela UFPE. Professora de Pós-graduação em História da UFPI.

2 Doutor em História pela UFPE. Professor do curso de História da Universidade Estadual do Piauí.
} 


\section{Introdução}

O presente texto visa discutir a história da educação piauiense na década de 1990, dando ênfase para as transformações derivadas da implantação de políticas públicas que afetaram principalmente a situação do atendimento ao educando no ensino público da rede estadual e à valorização do magistério (considerando remuneração e condições de trabalho). Assim, neste texto discute-se desde o funcionamento e as paralisações que afetaram as escolas estaduais no período, até a implantação de políticas públicas da envergadura da do Fundo de Manutenção e Desenvolvimento do Ensino Fundamental e de Valorização do Magistério - FUNDEF, e as repercussões que ela promoveu na instrução pública piauiense e brasileira.

O texto discute ainda como mesmo as paralisações de professores ocorridas nos períodos letivos de 1991 a 1994 foram atribuídas aos problemas derivados do ano de 1990 (período marcado pela perda do ano letivo), demonstrando que, além dos danos provocados na educação piauiense, pelo extenso período de greve naquele ano, esse episódio também foi utilizado pela administração estadual posterior, para eximir-se de muitas de suas responsabilidades governamentais. Já o período compreendido entre 1995 e 2000 teve como temática central a implantação do FUNDEF e a procura por consensos, embora esse cenário tenha convivido com tensões e questionamentos, como serão evidenciados pelas fontes consultadas, gerando, portanto, transformações, que passaram a conviver com as permanências no cenário educacional local.

\section{Brasil nos Anos de FHC: do dissenso ao consenso artificial}

A eleição do sociólogo Fernando Henrique Cardoso à presidência da República, em 1994, gerou muitas expectativas na população brasileira, fazendo Ribeiro afirmar que isso demonstrava a possibilidade de um "diálogo habermasiano", que teria como grande meta cicatrizar as fraturas 
deixadas pelos governos Fernando Collor e Itamar Franco, na relação entre Estado e sociedade civil.

Esse governo, que parecia encaminhar-se para a intensificação do campo das políticas sociais, envolveu-se, na verdade, com uma prática política mais voltada para atender aos interesses da política econômica gerenciada por organismos internacionais. Quando os conflitos sociais eram postos em foco, o governo respondia que o cerne do problema estava na execução dos programas sociais e não no volume de recursos à disposição dos agentes públicos. Ao invés, então, de se questionar em que essa execução demonstrava falhas, para poder corrigi-las, se é que, de fato, era este o problema central, o governo passou a defender a diminuição de investimentos na aplicação de programas sociais ou então a descentralização na sua aplicação, em relação aos estados e municípios.

Essa descentralização já vinha sendo proposta no campo fiscal desde a aprovação da Constituição de 1988, uma vez que pela primeira vez, os municípios passaram a ser considerados entes federativos autônomos, assim como já o eram estados e governo federal, mas essa autonomia restringia-se ao campo político-institucional, posto que, no campo econômico, social e administrativo, estava muito distante de se consolidar.

Ao analisar esse processo de descentralização das políticas sociais no Brasil, Arretche (2000) afirmou que houve alteração nos modelos assumidos pelos três níveis administrativos, o que fez com que estados e municípios tivessem uma elevação no volume de gastos com o social, enquanto a união reduziu seus investimentos neste campo, à medida que ampliava seus poderes fiscais na aplicação do que fora arrecadado (cobrança de impostos e campo administrativo), o que nos leva a concluir que o governo federal transferiu recursos e responsabilidades financeiras aos dois outros níveis, não atribuições administrativas nas decisões das políticas adotadas no período.

Esse modelo que caracterizou o Estado brasileiro mais como unitário que como federado também foi uma herança do regime militar vivido pelo País, que, em razão da reforma fiscal ocorrida em meados dos anos 1960, concentrou os principais tributos no poder da união, promovendo uma 
escassa autonomia tributária e fiscal nos estados e municípios. Isso contribuiu bastante para a centralização financeiro-administrativa vivida no Brasil, embora com a redemocratização, os governadores e prefeitos tenham passado a ter maior autoridade sobre alguns recursos fiscais.

Observa-se como a construção da descentralização, considerada por Arretche (2000, p. 16) como "a institucionalização no plano local de condições técnicas para a implementação de tarefas de gestão de políticas sociais", ainda apresentava muitos obstáculos em sua efetivação, exigindo do Brasil que atentasse para o que ela alertou, ao dizer que:

[...] dotado de uma esmagadora maioria de municípios de pequeno porte e historicamente dependentes da capacitação institucional dos governos estaduais e federal para a prestação de serviços sociais, o Brasil, para reformar ou descentralizar seu Sistema de Proteção Social, depende da ação política deliberada dos níveis mais abrangentes do governo (ARRETCHE, 2000, p. 71).

Assim, observa-se também, como toda e qualquer política social no Brasil tem direta relação e dependência com as propostas realizadas em nível federal, estando, portanto, as outras esferas administrativas vinculadas às deliberações da União. Foi o que se verificou ocorrendo também na segunda metade da década de 90. Com a iniciativa de implantar a descentralização das políticas, Fernando Henrique Cardoso usou como a grande bandeira de seu governo, o argumento de ter feito o possível pelo social, justificando que o reforço às políticas públicas viria a seu tempo, após a priorização do controle da inflação e da valorização da moeda nacional.

Tanto no primeiro quanto no segundo mandato, foi esta supremacia da economia, em detrimento das políticas sociais, que norteou o modelo administrativo desse governo, o que levou Costa (2000) a destacar que enquanto os anos 1980 foram marcados pela estagnação econômica, mas com avanços institucionais importantes, os anos 1990 mostraram-se como seu reverso: estabilização monetária, mas ao preço de sacrifícios no campo social. 
Esse período foi marcado pelo raciocínio de que era inútil opor-se à lógica econômica e às incontornáveis mudanças provocadas por ela. A educação, embora estivesse entre as cinco metas do governo, tinha por objetivo adequar-se às exigências do mercado, à medida que contribuiria para a construção de cidadãos produtivos para este mercado.

O que ilustrou isso adequadamente foram as conclusões a que chegou a Carta-Educação, aprovada no Fórum Capital-Trabalho, ocorrido em São Paulo. Em primeiro lugar, apresentou a carência da educação fundamental como principal entrave à construção da nação e, em segundo, mostrou a falta de condições do Brasil para competir internacionalmente em virtude da inadequação de seu sistema produtivo, ratificando que a superação dessa realidade só ocorreria por meio de mudança na política educacional vigente no País, e concluiu tal Fórum: "Vê-se por aí que não faltam matrículas, falta eficiência" (SHIROMA, 2002, p. 76).

O governo de Fernando Henrique Cardoso preferiu insistir no fato de que o problema estaria exclusivamente no mau uso dos recursos e não no seu pouco volume posto à disposição dos agentes públicos, responsabilizando apenas ao excesso de desperdício de verbas na execução de programas sociais pelo baixo rendimento apresentado por estes. Por isso, esse governo argumentou ter feito o possível pelo social, tendo primeiro que controlar a inflação e valorizar a moeda nacional, para somente depois intensificar o reforço com as políticas sociais, quando

pudesse. Parece, contudo, que no campo educacional os oito anos de mandato não foram suficientes para que isso pudesse ser feito, fortalecendo críticas como a de Costa (2000), que afirmou que nesse período a estabilização monetária manifestou-se em meio à instabilidade política e social.

\section{Piauí: a educação pública na segunda metade da década de $\mathbf{9 0}$}

Na esfera estadual, esse período foi marcado pela administração do governador Francisco de Assis Moraes Sousa, conhecido como Mão Santa, 
que administrou o Piauí por duas gestões consecutivas, de janeiro de 1995 a dezembro de 1998 e de janeiro de 1999 a novembro de 2001, pois, a exemplo do governo do presidente Fernando Henrique Cardoso, foi o primeiro governante do Piauí que pôde concorrer à reeleição, em virtude da alteração na legislação eleitoral.

Esse governo acompanhou significativas discussões e transformações no campo da educação escolar nacional, a exemplo da elaboração da Lei de Diretrizes e Bases da educação (LDB) n. 9.394/96, e do Fundo de Manutenção e Desenvolvimento do Ensino Fundamental e de Valorização do Magistério, o conhecido FUNDEF, instituído pela Emenda Constitucional $\mathrm{n}$. 14, de 12 de setembro de 1996, e regulamentado pela Lei 9.424/96, de 24/12/96 e pelo Decreto n. 2.264, de 27 de junho de 1997. No estado do Piauí, foi regulamentado pela Lei n. 4.926, de 30 de maio de 1997, e alterado pela Lei n. 4.998, de 30 de dezembro de 1997, começando a vigorar a partir de 1998.

Ao assumir a administração do Estado, o governador empossado em janeiro de 1995, enviou à Assembléia Legislativa, a Mensagem com o seguinte teor a respeito das condições em que, segundo ele, teria encontrado a educação:

Compõe-se de um parque escolar de 1.593 estabelecimentos de ensino para atender à demanda desde o pré-escolar ao $2^{\circ}$ grau (urbano e rural); dispõe de um quadro de 15.203 professores, atende a cerca de 318 mil alunos no Ensino Regular, e o Ensino Supletivo atende a uma clientela de 40 mil alunos. A infra-estrutura física encontra-se, todavia, profundamente danificada (PIAUÍ, 1995, p. 30).

É estranho notar que, ao mencionar as condições em que encontrava a educação, o governador, assim como os seus antecessores, tenha frisado que as escolas estavam danificadas ${ }^{3}$. Transcorridos três meses do então

\footnotetext{
${ }^{3}$ É uma constante nos discursos dos governos ao assumirem o Estado, a denúncia quanto à situação de depredação em que encontravam as escolas estaduais. Sinal de que, além de não terem sido reformadas, como alegavam, essas escolas continuavam enfrentando graves problemas nas condições físicas, sem mencionar as outras dimensões não tão visíveis.
} 
governo, um jornal local, noticiou matéria a respeito da condição em que se encontravam algumas escolas estaduais em alguns municípios do Piauí:

Os deputados Wellington Dias e Olavo Rebelo, do PT, denunciaram, ontem, que pais de alunos de Itaueira e Canto do Buriti estão fazendo 'vaquinha' para completar o salário dos professores. Nesta semana, os pais de alunos da Unidade Escolar Monsenhor Uchoa, de Itaueira, vão realizar o bingo de um filtro. O dinheiro arrecadado será utilizado na limpeza e compra de material para o colégio. Na mesma escola, as mães preparam a merenda dos alunos (MEIO NORTE, 28 mar. 1995).

Mais uma vez se pôde notar algumas semelhanças nas condições denunciadas por este jornal e as discutidas a respeito de períodos anteriores da história recente da educação piauiense. As características apresentadas por ele muito se assemelhavam às mostradas por algumas das fontes consultadas acerca do ano de 1990, ou seja, a arrecadação de dinheiro com a população para ajudar a comprar material para a escola, e a coleta entre os pais de alunos para pagar professores.

A depredação dos prédios escolares faz supor que isso provoca desgaste físico da estrutura arquitetônica dos mesmos, e prejuízos na autoestima dos agentes educacionais e dos alunos, pois uma escola danificada abala de várias maneiras os sujeitos que com ela convivem, inclusive no seu interesse em freqüentá-la e de nela permanecer. Geralmente esta dimensão é ignorada quando se discute as condições dos prédios escolares, mas é de expressiva relevância no processo do ensino-aprendizagem e na identificação de docentes e discentes com a escola em que atuam, tanto podendo beneficiar quanto prejudicar a relação desses sujeitos com o conhecimento.

Esse quadro de desgaste dos prédios escolares públicos revela que as mudanças na educação pública do Piauí, se ocorreram durante esse período, foram muito sutis e não se manifestaram expressivamente, deixando de ser sentidas por significativa parcela da sociedade, o que fez o mesmo jornal afirmar:

[...] Segundo os parlamentares do PT, a situação da educação, no interior do Estado é tão crítica, que em Itaueira, os bancos 
da Igreja da cidade foram cedidos às escolas e estão servindo como carteiras [...] (MEIO NORTE, 28 mar. 1995).

Como é possível perceber, a educação continuava apresentando problemas. Mas, de acordo com as fontes consultadas, foi possível notar também que a sociedade piauiense criou mecanismos de pressão sobre o governo, embora muitas vezes desestruturados, como o caso demonstrado pelo jornal expresso a seguir:

Representantes de cerca de 12 mil estudantes das escolas públicas estaduais que funcionam nos conjuntos Dirceu Arcoverde I e II, na Zona Leste, foram recebidos pelo Secretário de Educação do Estado, Ubiraci Carvalho. Eles entregaram documento em que reivindicavam condições para estudar. Milhares de alunos estão praticamente sem aulas desde o início do ano letivo, por falta de carteiras, material de expediente, banheiros e até mesmo professores (O DIA, 16 maio 1995).

Essa matéria jornalística, além de demonstrar que as escolas estaduais, tanto na capital quanto em outros municípios piauienses, enfrentavam graves problemas de estrutura e de atendimento aos alunos, revelou também que membros da sociedade piauiense já estavam se articulando para reivindicar seus direitos e exigir atendimento de qualidade nos estabelecimentos escolares. Isso, aparentemente não interferiu na estrutura governamental, mas denunciava ao poder público o grau de insatisfação e a capacidade de mobilização da sociedade, fazendo com que este se reestruturasse, senão suas ações, ao menos os discursos, para manter o diálogo com a sociedade.

Essa participação da sociedade foi tão significativa que os três líderes sindicais entrevistados durante a pesquisa afirmaram que os momentos em que a educação pública estadual mais avançou em conquista foi justamente quando professores ou alunos e seus familiares promoveram reivindicações sistematizadas e pressões junto ao Estado, evidenciando o que Bobbio (1999) afirmou ser a força que a sociedade civil teria sobre as esferas estatais: a pressão que faz o Estado repensar-se e reestruturar-se, conforme os anseios dessa sociedade, fortalecendo seus espaços de atuação. 
Foi assim quando os professores conquistaram o direito de receber vales-transportes, em 1992, bem como quando passaram a eleger diretamente os diretores escolares em Teresina e a garantir a criação de conselhos escolares, no final de 1995. Mas, como geralmente as conquistas da sociedade junto ao Estado são feitas de avanços e recuos (CARNOY, 2001), a eleição de diretores continuou limitada apenas à capital do Estado ${ }^{4}$.

Os problemas existentes nas escolas públicas, associados ao atraso de salários dos professores, fizeram com que os docentes entrassem em greve novamente a partir de agosto de 1996, que durou quarenta e cinco dias, conforme os registros do Sindicato dos Trabalhadores em Educação Básica Pública do Piauí (SINTE-PI). A situação no período estava tão grave que fez com que os professores retomassem uma prática já utilizada nos anos de 1989 e 1990, como evidencia a foto 1, ou seja, a mobilização para arrecadação de alimentos.

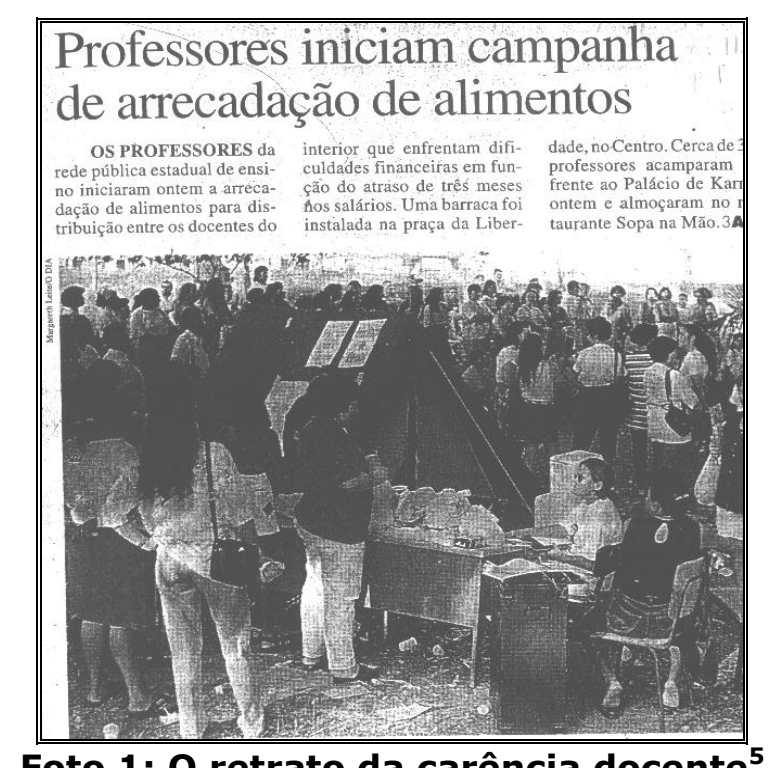

Este periódico noticiou que os alimentos arrecadados seriam doados aos docentes das escolas públicas do interior do Estado, que enfrentavam

4 Essas reivindicações integravam a pauta de mobilizações dos docentes desde aquelas do ano de 1981, sendo conquistadas parcialmente ao longo da década de 1990. Até o ano de 2000, as eleições para diretores das escolas públicas estaduais ocorriam apenas em Teresina.

${ }^{5}$ Fonte: O DIA, 14 ago. 1996.

História \& Ensino, Londrina, v. 18, n. 2, p. 43-76, jul./dez. 2012 
dificuldades financeiras em função do atraso de três meses nos salários, evidenciando o grau de problemas vividos por esses professores, sobretudo por que não recebiam o pagamento mensal nas mesmas datas daqueles da capital. Essa situação assemelhou-se à vivenciada pelos professores durante os mandatos de Alberto Silva e de Freitas Neto. Parece que na história da educação no Piauí Parmênides ${ }^{6}$ vive em constante conflito com Heráclito ${ }^{7}$.

Quanto à situação docente, a foto 2, publicada no jornal O Dia, revela muito o que os professores sentiam na época.

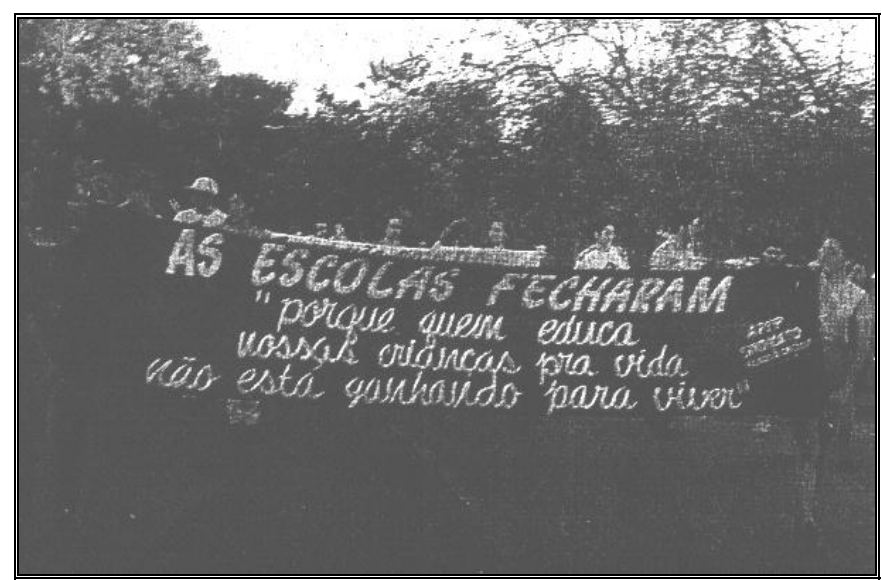

\section{Foto 2: Questão Salarial - Rupturas ou Permanências? ${ }^{8}$}

A faixa pretendia chamar a atenção da sociedade para os problemas enfrentados pelo magistério no Piauí: "As escolas fecharam porque quem educa nossas crianças para a vida não está ganhando para viver". Isso evidencia como estava a educação pública estadual antes da implantação do FUNDEF, sobretudo a situação do magistério. Mas a possibilidade da existência desse Fundo foi o argumento utilizado pelo então Secretário de Educação do Estado para tentar pôr fim à greve dos professores, antes mesmo que tivesse sido aprovado, o que só ocorreu em dezembro de 1996. Seu pronunciamento foi publicado por um jornal local, evidenciando o valor atribuído a essa política educacional:

\footnotetext{
6 Pensador grego defensor da ideia de que na história as permanências se sobrepõem às mudanças.

7 Também pensador grego que defendia a idéia de que as mudanças são a principal marca da história da humanidade.

${ }^{8}$ Fonte: O DIA, 22 ago.1996.
} 
[...] A partir de janeiro de 1997 entrará em vigor a emenda constitucional que cria o Fundo de Ensino Fundamental e de Valorização do Magistério. Este fundo é uma espécie de banco cujos recursos são obrigatoriamente depositados neles, em torno de $18 \%$ de recursos são divididos para as redes estadual e municipal de acordo com o per capita de alunos. É de R\$ 300,00 por cada aluno. Esse fundo prevê $60 \%$ dele, no mínimo, devem ser gastos com salários do professor que estiver efetivamente na sala de aula. Uma greve prolongada vai criar descrédito nos pais dos alunos. Em janeiro fugirão das escolas públicas. O que vai acontecer? Nós vamos ter menos recurso (O DIA, 6 ago.1996).

Refletindo acerca da fala do então Secretário, pôde-se até considerar válida a sua preocupação em desejar adequar a educação estadual aos critérios propostos pelo Fundo. Porém, o que provoca estranheza é o fato do interesse parecer limitar-se exclusivamente à necessidade de adequação às metas propostas pelo Ministério da Educação para obter os recursos financeiros previstos, e não por preocupação com a eficiência e com o atendimento ao discente, que deveria ser o principal. Esse depoimento mostra-se muito sintomático à medida que revela uma preocupação prioritária não com o dano social provocado por evasões de alunos, nem tampouco com a condição do magistério, mas com a perda de verbas que isso poderia significar. Isso demonstra como antes mesmo de ser implantado no Piauí, o FUNDEF, já teria despertado a inquietação do governo estadual em atentar mais para o funcionamento de suas escolas, para não ser penalizado na obtenção de recursos financeiros.

Embora essa preocupação revelasse a maneira como o poder público vinha tratando o atendimento educacional nas escolas estaduais, pouco intervindo eficientemente para solucionar os problemas geradores das greves, é muito relevante perceber como o governo estadual atribuía aos docentes em greve a possibilidade de perder recursos financeiros repassados pela União. Isso deixou perceber uma significativa alteração na forma de analisar e direcionar as políticas educacionais, uma vez ter sido o FUNDEF a primeira dessas ações de políticas educacionais a condicionar o envio de recursos financeiros, pela União ao número de alunos matriculados nas escolas municipais e estaduais (PINTO, 1999), fazendo com que os 
governantes dessas unidades federativas passassem a se preocupar com a permanência dos estudantes na escola.

A preocupação do governo estadual do Piauí, contudo, desconsiderava que a greve deflagrada em agosto de 1996, assim como as anteriores, envolvia professores das várias etapas da Educação Básica, não apenas do Ensino Fundamental, que era a contemplada com o FUNDEF. Mesmo assim, o representante do Executivo Estadual, sabendo que a diminuição de alunos implicaria em uma redução no envio de recursos quando o Fundo fosse implantado no Piauí, o utilizou como forma de convencer os grevistas a retornarem às suas atividades, alegando também que $60 \%$ dos recursos do FUNDEF deveriam ser gastos com salários de professores, sem especificar, porém, que isso só teria validade para os professores do Ensino Fundamental, nem tampouco explicar de que forma esse percentual incidiria sobre a remuneração docente.

Esses embates entre os representantes da Secretaria Estadual de Educação do Estado do Piauí (SEDUC ${ }^{9}$ ) e do Sindicato dos Trabalhadores em Educação Básica Pública do Piauí (SINTE-PI), demonstram como seus espaços de atuação estavam conflitantes, assim como revelam as incertezas desses órgãos quanto aos rumos que seriam tomados pelo Fundo no Piauí, inclusive quanto à data de sua implantação. O então Secretário de Educação afirmou que o FUNDEF seria implantado no Piauí em janeiro de 1997, mas isso só se efetivou em janeiro de 1998, aliás, como em todos os estados brasileiros, exceto o Pará, que o instituiu em 1997.

\section{Atendimento ao Aluno: entre a retórica e a ação}

Essa implantação repercutiu bastante na forma como a SEDUC passou a tratar a matrícula dos alunos, incentivando sua ampliação, como ilustra a fala do então Subsecretário de Educação, Oseas Gonçalves Sampaio, em

\footnotetext{
${ }^{9}$ Atualmente, a Secretaria de Educação do Estado do Piauí denomina-se de SEDUC, mas na década de 1990 denominavam-na de SEED-PI. Por isso, em algumas fontes utilizadas neste texto esta expressão deve ser entendida como referência à Secretaria de Educação.
} 
entrevista a um jornal: "(...) Se por um acaso alguém ficar sem se matricular por falta de vagas a gente pode criar até mesmo classes especiais (...)" (O DIA, 05 fev. 1998).

Os pais de alunos entrevistados destacaram que, a partir de 1998, o poder público estadual passou a demonstrar uma preocupação maior em ampliar as matrículas, mas que isso não se manifestou igualmente no item qualidade de ensino. Quanto a essa denúncia dos pais, o mesmo jornal local evidenciou o posicionamento do então presidente em exercício do SINTE-PI, em relação a esta postura da SEDUC:

[...] Mas o que está acontecendo é apenas a propaganda. Apesar de haver hoje um programa do governo no sentido de colocar as crianças em idade escolar do ensino fundamental, da primeira à oitava série estudando, o programa é voltado para o poder público e não para a população. Quanto mais crianças matriculadas mais dinheiro vai ser investido realmente na educação (O DIA, 05 fev. 1998).

Embora o presidente do SINTE-PI acusasse o governo de fazer apenas propaganda quando afirmava que ampliava as vagas de alunos no Ensino Fundamental, reconhecia que aumentando o número de discentes, maior seria o investimento na educação. Da mesma forma, a entrevista do Subsecretário mostrava a imensa preocupação da SEDUC em ampliar o número de alunos matriculados na rede estadual.

Essa preocupação com o número de alunos matriculados induz à associação disso ao condicionamento legal existente no Fundo que estabelecia que o repasse de verba deveria ser proporcionalmente ao número de alunos matriculados (PINTO, 1999). Essa veiculação legal promoveu debates em nível nacional para saber se isso contribuiu para a redução da exclusão escolar no Ensino Fundamental ou se incentivou administradores a registrarem matrículas irregulares, como as que foram reconhecidas pelo então Ministro da Educação, Paulo Renato Souza, ao afirmar terem sido comprovadas "153 mil matrículas irregulares em cinco estados" (O GLOBO, 04 abr. 1999).

Observando os quadros, é possível analisar o item matrículas e acompanhar o desenvolvimento do seu número nas três etapas da 
Educação Básica no Piauí, por tipo de estabelecimento de ensino, no período de 1988 a 2000.

\begin{tabular}{|c|c|c|c|c|c|c|c|c|}
\hline \multirow{2}{*}{$\begin{array}{c}\text { ANOS/ } \\
\text { REDES }\end{array}$} & FED. & EST. & MUNC. & PART. & FED. & EST. & MUNC. & PART. \\
\hline $\mathbf{1 9 8 8}$ & - & 10.930 & 1.754 & 9.244 & 374 & 15.790 & 51.712 & 8.780 \\
\hline $\mathbf{1 9 8 9}$ & - & 12.147 & 5.358 & 7.977 & 289 & 15.296 & 46.331 & 9.117 \\
\hline $\mathbf{1 9 9 0}$ & - & - & - & - & - & - & - & - \\
\hline $\mathbf{1 9 9 1}$ & - & 10.810 & 4.365 & 10.786 & 203 & 12.498 & 44.008 & 9.639 \\
\hline $\mathbf{1 9 9 2}$ & - & 11.778 & 4.151 & 8.946 & 532 & 10.408 & 40.296 & 9.425 \\
\hline $\mathbf{1 9 9 3}$ & - & 10.559 & 2.548 & 10.568 & 476 & 9.698 & 39.468 & 11.977 \\
\hline $\mathbf{1 9 9 4}$ & - & 14.345 & 3.087 & 15.725 & 618 & 25.776 & 94.137 & 18.206 \\
\hline $\mathbf{1 9 9 5}$ & - & 13.573 & 4.210 & 15.694 & 439 & 26.845 & 129.475 & 20.227 \\
\hline $\mathbf{1 9 9 6}$ & - & 13.564 & 6.340 & 15.758 & 137 & 23.203 & 87.447 & 16.440 \\
\hline $\mathbf{1 9 9 7}$ & - & 12.044 & 6.437 & 15.761 & 20 & 18.251 & 84.170 & 15.564 \\
\hline $\mathbf{1 9 9 8}$ & - & 12.164 & 5.834 & 16.052 & 119 & 12.842 & 61.959 & 13.483 \\
\hline $\mathbf{1 9 9 9}$ & - & 12.677 & 6.071 & 17.175 & 85 & 13.443 & 71.219 & 13.523 \\
\hline $\mathbf{2 0 0 0}$ & - & 12.527 & 5.933 & 19.058 & 53 & 14.640 & 74.563 & 14.520 \\
\hline $\mathbf{9}$
\end{tabular}

Quadro 1: Alunos Matriculados na Educação Infantil - Piauí (1988-2000) ${ }^{10}$

É possível notar pelo Quadro 1, que apresenta o número de matrículas na Educação Infantil no Piauí, dois momentos expressivos: em 1989 e em 1991 houve significativa redução nas matrículas nas escolas estaduais, tanto em Teresina, como nos demais municípios piauienses, o que faz supor que talvez seja em virtude do extenso período de greve em 1990, que não apresenta matrículas no referido quadro; já nos anos de 1997 e 1998, período da implantação do FUNDEF no Piauí, as escolas públicas estaduais em Teresina tiveram pequeno aumento no número de alunos matriculados, enquanto que nos municípios houve significativa redução na rede estadual. Isso provavelmente seja explicado em função de que o repasse dos recursos financeiros do FUNDEF seja feito considerando o número de matrículas ocorridas apenas no Ensino Fundamental, desconsiderando as

${ }^{10}$ Fonte: SEDUC. Dados coletados e organizados por FONTINELES, 2003. 
outras etapas de ensino (PINTO, 1999; DAVIES, 1999; GADOTTI, 2000; SAVIANI, 1998; SOUSA NETO, 2002), entre as quais a Educação Infantil, que notoriamente tem reduzido suas matrículas na rede oficial de ensino, nos municípios piauienses.

Em pesquisa feita sob encomenda do Programa de Apoio aos Secretários Municipais de Educação (PRASEM), a respeito dessa redução de matrículas na Educação Infantil, é possível perceber que,

No que se refere ao Piauí, o decréscimo total de matrículas é ainda mais acentuado $(-27,7 \%)$, sendo pequeno na rede federal que é bastante restrita $(-1,7 \%)$, significativo nas redes municipal $(-30.6 \%)$, estadual $(-29,1 \%)$ e privada ($19 ; 1 \%$ ) (BOAKARI; ROCHA, 1999, p. 20).

É interessante notar que mesmo em um trabalho financiado pelo UNICEF, MEC, Banco Mundial e pela UNDIME, tenha sido constatada a crescente e acentuada diminuição das matrículas na Educação Infantil. O que a provocou? Esse mesmo trabalho explicou:

No que se refere às classes de alfabetização, verifica-se uma queda significativa na matrícula, se comparado o período $96 / 98$, tanto em nível nacional como regional e local. A rede municipal, que apresentava os números mais expressivos, teve seus índices reduzidos gradativamente, chegando a perder $49.4 \%$ de alunos no Brasil, 57,0 \% no Nordeste e 51,3 $\%$ no Piauí. As quedas verificam-se igualmente nas redes estadual, particular e federal e, ao que tudo indica, decorrem de um posicionamento, assumido mais fortemente a partir da criação do FUNDEF (BOAKARI; ROCHA, 1999, p. 21).

Observa-se que a priorização do FUNDEF em relação ao Ensino Fundamental contribuiu significativamente para o decréscimo de matrículas na Educação Infantil e, além disso, para o surgimento de estratégias para obter recursos do Fundo, alterando situações de atendimento, como também revelou essa pesquisa:

Os alunos das classes de alfabetização passaram a ser matriculados no ensino fundamental, o que melhorou 0 desempenho dos municípios que passam a poder contar com 
um maior número de matrículas e a receber os respectivos recursos financeiros (BOAKARI; ROCHA, 1999, p. 21).

Esse trabalho não só não questiona os subterfúgios usados pelos municípios piauienses, quanto destaca que isso os fez obter mais recursos financeiros do FUNDEF, que deveriam ser aplicados exclusivamente em Ensino Fundamental. Mas essa prática não foi exclusiva das redes municipais de ensino, uma vez que a rede estadual também passou a orientar a matrícula de crianças de seis anos de idade como se estivessem cursando o Ensino Fundamental, ampliando de 8 para 9 anos o tempo de atendimento deste, conforme afirmaram as diretoras e secretárias consultadas nas escolas investigadas ${ }^{11}$.

Essa determinação do Fundo gerou críticas em virtude da crença de que ele reduziria o número de vagas nas outras etapas da Educação Básica. Mas não foi bem isso que se verificou ao analisar o número de matrículas no Ensino Médio, nas escolas estaduais do Piauí, no período de 1988 a 2000, como revela o Quadro 2:

\begin{tabular}{|c|c|c|c|c|c|c|c|c|}
\hline \multirow{2}{*}{$\begin{array}{l}\text { ANOS/ } \\
\text { REDES }\end{array}$} & \multicolumn{4}{|c|}{ Capital } & \multicolumn{4}{c|}{ Interior do Estado } \\
\cline { 2 - 9 } & FED. & EST. & MUNC. & PART. & FED & EST. & MUNC. & PART \\
\hline $\mathbf{1 9 8 8}$ & 3.356 & 13.894 & 693 & 11.294 & 244 & 12.418 & 1.204 & 6.650 \\
\hline $\mathbf{1 9 8 9}$ & 3.187 & 14.211 & 714 & 8.864 & 284 & 15.107 & 1.303 & 6.829 \\
\hline $\mathbf{1 9 9 0}$ & - & - & - & - & - & - & - & - \\
\hline $\mathbf{1 9 9 1}$ & 4.030 & 11.742 & 720 & 9.338 & 246 & 12.379 & 1.523 & 6.849 \\
\hline $\mathbf{1 9 9 2}$ & 4.070 & 12.949 & 801 & 6.106 & 298 & 13.409 & 1.821 & 6.517 \\
\hline $\mathbf{1 9 9 3}$ & 3.995 & 15.122 & 824 & 6.623 & 343 & 14.582 & 1.633 & 7.136 \\
\hline $\mathbf{1 9 9 4}$ & 4.091 & 16.025 & 915 & 8.771 & 512 & 15.816 & 1.603 & 7.757 \\
\hline $\mathbf{1 9 9 5}$ & 3.596 & 15.590 & 792 & 10.120 & 535 & 16.760 & 1.337 & $* 13$ \\
\hline $\mathbf{1 9 9 6}$ & 2.956 & 17.907 & 745 & 9.199 & 538 & 17.893 & 1.368 & 7.130 \\
\hline $\mathbf{1 9 9 7}$ & 3.183 & 17.409 & 738 & 11.338 & 611 & 19.722 & 1.777 & 8.740 \\
\hline $\mathbf{1 9 9 8}$ & 2.931 & 20.537 & 732 & 14.169 & 745 & 24.295 & 2.365 & 8.692 \\
\hline
\end{tabular}

${ }^{11}$ No período o Ensino Fundamental compreendia regularmente oito anos e não nove, como alguns gestores informavam em seus relatórios. Somente em 2006 o Presidente da República sancionou a Lei no 11.274 que regulamenta o ensino fundamental em 9 anos, no dia 06 de fevereiro.

${ }^{13}$ A SEDUC não forneceu o número de alunos matriculados nas escolas particulares nos municípios piauienses no ano de 1995, alegando problemas nos registros internos. 


\begin{tabular}{|l|l|l|l|l|l|l|l|l|}
\hline $\mathbf{1 9 9 9}$ & 2.069 & 24.785 & $* * 14$ & 14.277 & 1.044 & 30.689 & 2.503 & 8.985 \\
\hline $\mathbf{2 0 0 0}$ & 1.810 & 32.810 & & 15.277 & 1.156 & 43.521 & 3.301 & 9.982 \\
\hline
\end{tabular}

Quadro 2: Alunos Matriculados no Ensino Médio - Piauí (1988-2000) ${ }^{15}$

O Quadro 2 apresenta que nas escolas estaduais, situadas na capital e no interior piauiense, houve significativo crescimento no número de matrículas de alunos no Ensino Médio ao longo da década de 1990, sobretudo a partir do ano de 1996, após um período de decréscimo e de oscilação nas matrículas, provocado pelo abalo na credibilidade da rede estadual de ensino após a greve ocorrida em 1990, o que é demonstrado pela redução de matrículas na rede estadual entre 1989 e 1991. Crescimento esse que foi sendo recuperado no Piauí principalmente entre os anos de 1997 e 1998, período de implantação do FUNDEF no Estado, e que foi aumentando significativamente nos anos seguintes, até 2000.

Tanto é que entre 1997 e 1998, a rede estadual de ensino cresceu em Teresina, em $17,96 \%$ no número de matrículas e nos demais municípios, cresceu $28,25 \%$ no total de matrículas, continuando a crescer nos anos seguintes em ambas as regiões piauienses.

Isso contraria os temores que alguns estudiosos nacionais diziam sentir de que os estados brasileiros negligenciassem essa etapa da Educação Básica. Pode-se atribuir isso ao fato de ser considerada atribuição prioritária dos estados a administração do Ensino Médio, segundo o previsto pela LDB n. 9.394/96. Tanto é, que a partir de 1999, a rede municipal de ensino de Teresina não possuía nenhuma matrícula em seus registros nesse nível da Educação Básica; já nos demais municípios, essas matrículas foram ampliadas no mesmo período, talvez em função da cobertura do ensino estadual não ser suficiente à demanda existente nestes locais e ficar sob responsabilidade do Poder Executivo Municipal tal delegação.

Atribuímos, também, esse significativo crescimento, à pressão da sociedade almejando a ampliação do atendimento nessa etapa da Educação Básica, como demonstrado anteriormente, em virtude da constante

\footnotetext{
${ }^{14}$ A rede municipal de Teresina suspendeu o atendimento aos alunos de Ensino Médio a partir do ano de 1999.

${ }^{15}$ Fonte: SEDUC-PI, In. FONTINELES, 2003.
} 
propaganda do governo estadual para que esta procurasse matricular seus filhos no Ensino Fundamental nas escolas públicas estaduais, fazendo com que ela também se mobilizasse por escolas que atendessem os alunos quando concluíssem esta etapa, estendendo o atendimento do Ensino Médio, como forma de possibilitar aos discentes prosseguirem seus estudos.

O próprio estudo financiando pelo PRASEM reconhece que a pressão da sociedade foi determinante para que o atendimento nessa etapa se dilatasse:

\begin{abstract}
Em nível de País e da Região Nordeste, a rede estadual foi a que apresentou crescimento mais significativo, ao contrário do Piauí, onde o maior incremento deu-se na rede municipal, o que parece ser decorrente da crescente demanda de alunos que terminam o ensino fundamental e, não tendo condições de serem absorvidos pela rede estadual, nem de se matricularem na rede privada, pressionam o município no sentido de sua vontade de cursar o nível do ensino médio (BOAKARI; ROCHA, 1999 , p. 26).
\end{abstract}

Mas esse acentuado número de alunos concluindo o Ensino Fundamental não é visto por significativa parcela dos professores pesquisados, ou seja, 32 dos 43 que responderam os questionários nesta pesquisa, afirmaram não ser uma conquista da educação e sim fruto de uma grande pressão governamental para evitar reprovação e evasão de alunos no Ensino Fundamental, o que fez dilatar e fragmentar demais os critérios avaliativos para poderem cumprir as metas previstas, e inseriremse naquelas exigências previstas a serem atingidas pelos acordos com instituições internacionais. A maioria dos professores não explicitou esses acordos em suas falas, mas disseram considerar estranho que os governos, sobretudo a partir da $2^{a}$ metade da década de 1990 , tenham demonstrado tanto interesse nos percentuais de aprovação discente e na sua permanência na escola, pouco contribuindo para que o processo do ensinoaprendizagem fosse visto e melhorado durante sua execução limitando-se apenas em analisar seu desfecho avaliativo. Isso se revelou uma grande preocupação entre esses docentes. Os que citaram o interesse de instituições internacionais na crescente aprovação da escola pública foram 
os professores que estavam se graduando em cursos de licenciatura plena e os que já eram licenciados.

Já em relação ao Ensino Fundamental, o FUNDEF foi criado propondo melhorá-lo efetivamente. No caso das escolas públicas piauienses, pode-se observar que, a partir de sua institucionalização, as matrículas tornaram-se uma constante preocupação do poder público estadual e o funcionamento dessas escolas tornou-se mais regular, embora ainda com muitas paralisações e muitas carências.

Após um período marcado por sucessivos declínios nas matrículas das escolas da rede estadual neste nível de ensino, acentuados sobretudo com a perda do ano letivo em muitas unidades escolares no ano de 1990, essa rede voltou a crescer, em Teresina, entre os anos de 1997 e 1998, enquanto nos demais municípios isso passou a ocorrer entre os anos de 1998 e 1999, como demonstra o Quadro 3:

\begin{tabular}{|c|c|c|c|c|c|c|c|c|}
\hline \multirow{2}{*}{$\begin{array}{c}\text { REDES } \\
\text { ANOS }\end{array}$} & FED. & EST. & MUNC. & PART. & FED. & EST. & MUNC. & PART. \\
\cline { 2 - 9 } $\mathbf{1 9 8 8}$ & - & 80.170 & 27.124 & 26.126 & 1.274 & 195.881 & 243.729 & 38.324 \\
\hline $\mathbf{1 9 8 9}$ & - & 79.538 & 30.787 & 26.670 & 1.213 & 199.306 & 255.958 & 39.681 \\
\hline $\mathbf{1 9 9 0}$ & - & - & - & - & - & - & - & - \\
\hline $\mathbf{1 9 9 1}$ & - & 70.023 & 31.365 & 39.171 & 1.091 & 181.488 & 238.227 & 40.753 \\
\hline $\mathbf{1 9 9 2}$ & - & 76.235 & 40.928 & 32.486 & 1.407 & 181.513 & 237.310 & 37.664 \\
\hline $\mathbf{1 9 9 3}$ & - & 74.200 & 41.828 & 31.417 & 916 & 181.906 & 239.258 & 39.205 \\
\hline $\mathbf{1 9 9 4}$ & - & 66.309 & 47.189 & 35.130 & 1.041 & 181.452 & 248.100 & 38.454 \\
\hline $\mathbf{1 9 9 5}$ & - & 59.246 & 58.319 & 40.656 & 1.032 & 200.773 & 467.078 & 41.673 \\
\hline $\mathbf{1 9 9 6}$ & - & 57.721 & 48.946 & 40.329 & 405 & 185.638 & 247.041 & 35.995 \\
\hline $\mathbf{1 9 9 7}$ & - & 57.272 & 52.519 & 40.491 & 326 & 183.445 & 308.967 & 36.570 \\
\hline $\mathbf{1 9 9 8}$ & - & 60.027 & 55.182 & 38.981 & 644 & 174.557 & 370.414 & 31.442 \\
\hline $\mathbf{1 9 9 9}$ & - & 76.276 & 55.231 & 32.778 & 116 & 187.983 & 400.489 & 28.367 \\
\hline $\mathbf{2 0 0 0}$ & - & 77.115 & 57.838 & 31.487 & 164 & 178.928 & 409.333 & 26.515 \\
\hline
\end{tabular}

Quadro 3: Alunos Matriculados no Ensino Fundamental - Piauí (19882000) $)^{16}$

Mediante o apresentado no Quadro 3, pode-se inferir algumas considerações. Primeiro, que as escolas da rede oficial do estado do Piauí, sofreram um dano irreparável no ano de 1990, evidenciado principalmente

${ }^{16}$ Fonte: SEDUC, 2003, In: FONTINELES, 2003. 
pela falta de registros de matrículas desse ano; segundo, a ausência de regularidade no ensino público estadual promoveu um crescimento na evasão de alunos nesse tipo de estabelecimento em todas as etapas da Educação Básica; e terceiro, o FUNDEF contribuiu para ampliar o rigor no controle federal a respeito da regularidade no funcionamento das escolas públicas do Ensino Fundamental, promovendo uma estagnação no processo de redução de matrículas, passando a haver significativo crescimento na rede estadual de ensino no Piauí, a partir do ano de 1998, demonstrando que mesmo a inconstância na atuação dessas escolas tendo abalado sua credibilidade junto à sociedade piauiense, quando há uma maior regularidade em seu financiamento, amplia o número de alunos atendidos por ela.

\section{FUNDEF no Piauí: início de sua fiscalização}

Atribuir ao FUNDEF uma retomada no crescimento do número de matrículas no Ensino Fundamental da rede estadual de ensino do Piauí não significa, contudo, que se defenda que a implantação e aplicação desse Fundo não tenha apresentado problemas.

Consultando Relatórios do Tribunal de Contas do Estado do Piauí (TCEPI), que é o responsável legítimo pela fiscalização a respeito da aplicação dos recursos do Fundo, segundo o que atribui o próprio Ministério da Educação, ao estabelecer que os "órgãos responsáveis pelos sistemas de ensino, assim como os Tribunais de Contas da União, dos Estados e Municípios, criarão mecanismos adequados à fiscalização do cumprimento pleno do disposto no artigo 212 da Constituição" (BRASIL, 1999, p. 06), foram obtidas informações importantes a respeito de problemas detectados na implantação do FUNDEF no Estado, como está evidenciado na prestação de contas da SEDUC, correspondente ao exercício 1998. O relatório do TCEPI afirma que: 
Em relação ao FUNDEF (...), destaca-se o descumprimento dos artigos 19 e 21 da Resolução n. 1.606/98, de 18/06/98, no que concerne ao envio a esta Corte de Contas da lei que institui o conselho de acompanhamento e controle social, do ato de designação ou indicação, quando houver, do gestor da aplicação dos recursos vinculados ao Fundo; da lei instituidora do plano de carreira e remuneração do magistério; dos demonstrativos financeiros mensais dos recursos do FUNDEF; da relação nominal dos profissionais do magistério com lotação e remuneração; e dos demais balancetes com as alterações supervenientes, por ventura ocorridas (PIAUÍ, TCE, 1999, p. 1-2).

Analisando este documento, pode-se observar as irregularidades constatadas no Piauí, pelo Tribunal de Contas do Estado, no ano da implantação do FUNDEF, por meio do desrespeito às determinações estabelecidas pela Lei de criação deste Fundo. A respeito da implantação do Conselho de Acompanhamento e Controle Social do FUNDEF, este Relatório afirma que o mesmo "foi instituído em 04/11/98, fora do prazo estipulado pela Lei 9.424/96 (180 dias a partir de sua vigência, ou seja, entre janeiro e junho de 1997). Era composto por 10 membros, incluídos os Secretários de Educação e da Fazenda" (PIAUÍ, TCE, 1999, p. 12).

Este Relatório prosseguiu afirmando que tal Conselho só teria se reunido, até a data de 04/11/99, por duas vezes, para aprovação do Regimento Interno, não tendo podido estabelecer "nenhum controle social sobre o FUNDEF" (PIAUÍ, TCE, 1999, p. 13), como a exigência legal para que se pudesse evitar desvio de verbas ou malversação.

Nesse mesmo documento, as constatações a que chegou a citada Corte foram as mesmas, demonstrando que as dificuldades relativas à adequação legal no que estabelece o FUNDEF no Piauí ainda persistiam, o que muito tinha dificultado saber se os recursos estariam sendo aplicados para os fins a que foram destinados.

\section{O Magistério: conquistas em sua valorização?}

Durante esta pesquisa foi possível detectar que as principais dificuldades enfrentadas pelo ensino público estadual no período de 1988 a 
2000 estiveram direta ou indiretamente relacionadas à situação do magistério, seja relativas a questões salariais ou as de qualificação profissional.

Assim, ao analisar o que era exposto acerca de vários governos estaduais que administraram o Estado durante este período, verificou-se que tal problema foi retomado e manifestado em todos. Por isso, não deve causar estranheza 0 fato de que, durante a pesquisa empírica (principalmente com a aplicação dos questionários e realização das entrevistas) a maioria dos professores atribuiu como principal característica do governo de Francisco de Assis Moraes Sousa, o Mão Santa, a valorização do magistério por meio da qualificação promovida pelos cursos de licenciatura plena, realizados em convênio entre a SEDUC e a Universidade Estadual do Piauí (UESPI). Apenas 11 desses professores fizeram alguma menção à determinação legal a respeito de tal qualificação, dos quais nove souberam mencionar qual era. Desses, relacionaram-na às deliberações constantes na LDB; dois a relacionaram aos recursos do FUNDEF; e três, mencionaram a LDB e o FUNDEF como complementares e responsáveis pela existência dessa qualificação.

Isso revela o quanto ainda estava obscura para os professores a origem dos recursos aplicados em sua qualificação, fazendo com que a atribuíssem a vontades pessoais de alguns governantes. É interessante notar que, mesmo entre os professores pesquisados, que não estavam fazendo nenhum curso de qualificação via convênio SEDUC/UESPI, também foi feita a associação entre o governo Mão Santa e o apoio à qualificação do magistério.

É fato que esses cursos de qualificação foram intensificados, no Piauí, durante a administração desse governador. Porém, não se pode ignorar que isso se deu muito em função da aprovação da LDB e da instituição do FUNDEF. A primeira, ao prever e exigir, até o ano de 2006, a qualificação do magistério por meio de cursos de licenciatura plena e, o segundo, estabelecendo os recursos que as Unidades Federadas aplicariam em tais qualificações para professores do Ensino Fundamental, que não possuíssem tal formação e que estivessem em pleno exercício do magistério. 
No caso do Piauí, antes mesmo da implantação do FUNDEF, já havia cursos de formação de professores via convênio SEDUC/UESPI. No período contemplado por esta pesquisa, isso foi encontrado pela primeira vez na divulgação do vestibular para Licenciatura Curta em Ciências e Letras, feita pelo jornal O Estado, de 15/10/92, que apresentava a distribuição de vagas entre municípios piauienses, conforme apresenta o Quadro 4.

\begin{tabular}{|c|c|c|c|c|c|}
\hline \multirow{3}{*}{$\begin{array}{c}\text { Município } \\
\text { Pólo }\end{array}$} & \multicolumn{5}{|c|}{ Cursos/Vagas } \\
\hline & \multicolumn{2}{|c|}{ Ciências } & \multicolumn{2}{|c|}{ Letras } & \multirow{2}{*}{$\begin{array}{c}\text { Total } \\
\text { de } \\
\text { Vagas }\end{array}$} \\
\hline & $\begin{array}{c}\text { Rede } \\
\text { Estadual }\end{array}$ & $\begin{array}{c}\text { Rede } \\
\text { Municipal }\end{array}$ & $\begin{array}{c}\text { Rede } \\
\text { Estadual }\end{array}$ & $\begin{array}{c}\text { Rede } \\
\text { Municipal }\end{array}$ & \\
\hline Corrente & 26 & 14 & 26 & 14 & 80 \\
\hline Floriano & 23 & 17 & 23 & 17 & 80 \\
\hline Parnaíba & 24 & 06 & 24 & 06 & 60 \\
\hline Picos & 25 & 20 & 25 & 20 & 90 \\
\hline Piripiri & 33 & 12 & 33 & 12 & 90 \\
\hline $\begin{array}{c}\text { São } \\
\text { Raimundo } \\
\text { Nonato }\end{array}$ & 31 & 09 & 31 & 09 & 80 \\
\hline Teresina & 22 & 18 & 22 & 18 & 80 \\
\hline $\begin{array}{l}\text { Valença } \\
\text { do Piauí }\end{array}$ & 27 & 13 & 27 & 13 & 80 \\
\hline
\end{tabular}

Quadro 4: Distribuição de Vagas dos Cursos Superiores Oferecidos pela FADEP aos Professores da Rede Pública do Piauí - Vestibular $1993^{17}$

Todavia, foi a partir do FUNDEF que se viabilizou a possibilidade de ampliar a qualificação do magistério, visando reverter a difícil situação enfrentada pela categoria, evidenciada por jornal local:

Escândalo nacional. O Estado do Piauí tem o maior percentual de professores em salas de aulas que não concluíram o primeiro grau. Para cada cem professores em atividade docente nas escolas piauienses, 21 não concluíram o primeiro grau, apurou o Departamento de Estatísticas do Ministério da Educação e Cultura (MEC) em projeções feitas a partir dos dados preliminares do Censo Educacional de 1995 (O DIA, 26 set. 1996).

A matéria referida foi a única informação encontrada a esse respeito durante a pesquisa, haja vista nem o SINTE-PI nem a SEDUC terem-nos informado dados a respeito do nível de qualificação de seus professores.

${ }^{17}$ Fonte: O Estado, 15 out. 1992.

História \& Ensino, Londrina, v. 18, n. 2, p. 43-76, jul./dez. 2012 
Considerando, portanto, a situação apresentada por este jornal, evidenciava-se a necessidade e a importância de ações de políticas públicas do cunho da do FUNDEF que reserva $60 \%$ dos recursos para qualificação do magistério.

Há, contudo, divergências quanto ao cumprimento do que prevê a lei a respeito desses cursos de qualificação, uma vez que somente os professores de Ensino Fundamental, em pleno exercício do magistério e que não tivessem licenciatura plena deveriam ser beneficiados com tais cursos. Mas, conforme o Relatório do TCE-PI, fica difícil saber se os critérios exigidos foram cumpridos, uma vez que, nos casos dos professores matriculados nos cursos de qualificação entre os anos de 1998 a 2000, não existia controle a esse respeito:

\begin{abstract}
Embora disponha de um Departamento de Recursos Humanos, de uma Divisão de Pessoal, de uma Seção de Folha de Pagamento e de um Departamento de Ensino Fundamental, mesmo assim a SEED não conseguiu fornecer a relação dos profissionais do magistério, nem do pessoal administrativo, vinculados ao Ensino Fundamental. Dessa forma não se pode afirmar que os recursos do FUNDEF foram utilizados, exclusivamente, como determina a lei, em despesas do Ensino Fundamental (PIAUÍ, TCE, 1999, p. 13-14).
\end{abstract}

Essa falta de controle acerca do número de professores que estavam sendo qualificados com os recursos do FUNDEF foi mencionada também pelo TCE-PI ao avaliar o exercício de 1999 e detectar que o Convênio n. 166/98, firmado entre a SEED-PI e a Fundação Universidade Estadual do Piauí (FUESPI), visava qualificar "professores do ensino fundamental e ensino médio, ${ }^{18}$ da rede estadual com oferta de cursos de licenciatura plena, nos campi da FUESPI, com recursos do FUNDEF e ou Tesouro Estadual" (apud PIAUÍ, TCE, 2000, p. 17).

Esse Relatório alertou ainda que o convênio não estabelecia a quantidade de professores a serem qualificados nos 23 municípios que seriam implantados os cursos, lembrando que "os professores do ensino médio não poderiam estar incluídos nos cursos de capacitação, mas como

${ }^{18}$ Grifo constante do relatório do Tribunal de Contas do Estado.

História \& Ensino, Londrina, v. 18, n. 2, p. 43-76, jul./dez. 2012 
nem a própria SEED sabe quais professores foram beneficiados, não se pode afirmar que a SEED utilizou recursos do FUNDEF para capacitar professores do ensino médio" (PIAUÍ, TCE, 2000, p. 17).

O Relatório afirma também que o pagamento do citado convênio fora suspenso e firmado outro em 2000, "em que no objeto se especifica a quantidade de professores a serem capacitados e se restringe apenas aos professores do ensino fundamental" (PIAUÍ, TCE, 2000, p. 18).

É muito importante notar o papel do acompanhamento social das políticas públicas, porque as ajuda a aperfeiçoarem suas aplicações tornado-as mais eficientes, a exemplo dos cursos de qualificação dos professores da rede estadual de ensino, ainda mais com o agravante da falta de controle pela SEED-PI, o que dificultava saber se quem estava sendo qualificado era professor em efetivo exercício do magistério fundamental ou se era de outra etapa ou se exercia outra função que não a de professor.

\section{Magistério: efetiva valorização?}

Outra dificuldade que acompanhou a pesquisa acerca do FUNDEF no Piauí foi saber se ele efetivamente conseguiu promover a valorização do magistério no item pagamento de salário. Primeiro, isso se deu em função de a SEDUC ter tornado público não saber quais docentes estavam trabalhando e em que etapa de ensino, impossibilitando descobrir se o Fundo auxiliou o crescimento de salários de professores do Ensino Fundamental. Conforme o questionário enviado ao SINTE-PI, não havia, até o ano de 2000, diferenciação alguma entre os salários dos professores, conforme a etapa em que trabalhassem, deixando transparecer concordar com o posicionamento da Confederação Nacional dos Trabalhadores em Educação (CNTE), que afirmou:

O MEC tem trombeteado que os salários dos professores subiram com o FUNDEF. Não se pode negar que alguns municípios, onde havia pouca arrecadação e muitos alunos, e, 
portanto, pagavam salários de miséria a seus professores, passaram a ter recursos para um vencimento inicial de $\mathrm{R} \$$ 200,00 ou até mais em 1998. O que não se fala é que somente $20 \%$ dos professores tiveram aumento substancial em sua remuneração e que 1999 e 2000 foram sacudidos por dezenas de greves nas redes estaduais e centenas nas municipais, porque o arrocho continuou obrigando os professores a multiplicar suas jornadas ou procurar outros trabalhos para sobreviver (CNTE, 2 a 9/2001).

Gadotti também se posicionou ao dizer que "O governo investe pouco em educação, não houve melhoria salarial apesar do Fundão, enfim, o sistema de ensino está sendo sustentado pelo salário não pago ao trabalhador em educação" (2000, p. 133). O que se nota, mediante estas críticas, é um acentuado número de pessoas insatisfeitas não com o FUNDEF em sua essência, mas com as falhas e lacunas existentes em sua aplicação.

Todavia, contrapondo-se a essas críticas e questionamentos, o MEC procurou responder por meio do Balanço de primeiro ano do FUNDEF, afirmando que:

Com critério redistributivo dos recursos e a garantia de uma significativa parcela do fundo para remuneração do magistério, importantes transformações ocorreram no cenário de financiamento do ensino fundamental ao movimentarem-se recursos dos governos com maior capacidade financeira e/ou com um baixo nível de participação no atendimento escolar na direção dos municípios em situação inversa. Com isso, mais de 2.700 municípios obtiveram ganhos financeiros com o FUNDEF em 1998, superando 3.200 municípios em 1999 (BRASIL, 1999, p. 05).

Não ignoramos que o lugar social do qual falam esses sujeitos é decisivo em suas defesas teóricas. Mas, os posicionamentos supramencionados são muito reveladores, pois demonstram os dilemas e embates teórico-sociais que permeavam a visão sobre a implantação e aplicação dessa política social na educação escolar brasileira, contribuindo também para evidenciar o quanto a palavra consenso estava distante dos vocabulários quando se discutia a respeito do FUNDEF.

Essa preocupação presente na discussão a respeito desse Fundo, que, aliás, integra sua denominação, se ele tem contribuído para a valorização 
do magistério tem provocado alguns questionamentos em nível nacional e local. A respeito disso é importante analisar o que estabelece a própria Lei n. 9.424/96, em seu artigo $9^{\circ}$ :

Os Estados, o Distrito Federal, os municípios deverão, no prazo de seis meses da vigência desta Lei, dispor de novo Plano de Carreira e Remuneração do Magistério, de modo a assegurar:

I - a remuneração condigna dos professores do ensino fundamental público, em efetivo exercício do magistério;

II - o estímulo ao trabalho em sala de aula;

III - a melhoria da qualidade do ensino.

Os Relatórios do TCE-PI evidenciaram, como já foi analisado, algumas dificuldades que impossibilitaram que este Fundo cumprisse suas determinações legais no estado do Piauí. Em relação ao Plano de Carreira e Remuneração do Magistério que, segundo o SINTE- PI, até o ano de 2000, ainda não tinha sido aprovado, o TCE-PI afirmou que: "Quanto ao Plano de Carreira e Remuneração do Magistério, exigido pela Lei n. 9.424/96, que, segundo informações da Secretaria, foi elaborado, ainda não foi aprovado e tampouco o projeto de lei foi apresentado à equipe de inspeção" (PIAUÍ, TCE, 2000, p. 14).

Semelhante observação foi feita pelo Relatório do TCE-PI a respeito do exercício de 1998, o que reflete um acentuado atraso no cumprimento de uma exigência da própria lei de criação do FUNDEF. E, o mais grave, isso se aplica a todas as etapas da educação escolar estadual, o que muito tem dificultado a configuração do item valorização do magistério, um dos objetivos primordiais desse Fundo.

Reforçou tal dificuldade o fato de o pagamento dos salários não ter expressado aumento significativo. Avaliando esse item, o TCE-PI, ao analisar o exercício de 1998, publicou o seguinte parecer em $1^{\circ}$. de dezembro de 1999:

Exemplificando, verificou-se nos espelhos de contra-cheques dos meses de dezembro/97, outubro/98 e junho/99, de três professores, escolhidos aleatoriamente, que as variações a maior ocorridas nos seus vencimentos, foram devidas ao aumento do número de horas trabalhadas, ou seja, passaram 
de 20 horas para 40 horas semanais, e não a aumento salarial (PIAUÍ, TCE, 1999, p. 13).

Mediante esta avaliação do TCE-PI, fica muito difícil afirmar que os salários dos professores da rede estadual de ensino tenham recebido incentivo após a criação do FUNDEF, sejam aqueles que trabalham no Ensino Fundamental, que deveriam ser contemplados por este Fundo, sejam os das outras etapas da Educação Básica, pois a diferenciação salarial, no estado do Piauí, não é feita conforme a etapa de atuação e sim de acordo com a qualificação dos professores, como demonstrado no Quadro 5, que compara os salários recebidos por esses professores, em 1995 e em 1991, destacado pelo Núcleo de Pesquisadores do FUNDEF no Piauí ${ }^{19}$ :

\begin{tabular}{||c|c|c|c|c|c|c||}
\hline \hline CLASSES & \multicolumn{3}{|c|}{ VENCIMENTO OUTUBRO DE } & \multicolumn{3}{c|}{ VENCIMENTO AGOSTO DE } \\
\hline $\begin{array}{c}\mathbf{2 0} \\
\text { HORAS }\end{array}$ & Vcto & Regência & Total & Vcto & Regência & Total \\
\hline $\begin{array}{c}\text { Classe A - } \\
\text { 20h }\end{array}$ & 102,18 & 40,87 & 143,05 & 180,00 & 72,00 & 252,00 \\
\hline $\begin{array}{c}\text { Classe B - } \\
\text { 20h }\end{array}$ & 103,83 & 41,53 & 145,36 & 181,65 & 72,66 & 254,31 \\
\hline $\begin{array}{c}\text { Classe C - } \\
\text { 20h }\end{array}$ & 105,48 & 42,19 & 147,67 & 183,30 & 73,32 & 256,62 \\
\hline $\begin{array}{c}\text { Classe D - } \\
\text { 20h }\end{array}$ & 107,13 & 42,85 & 149,98 & 184,95 & 73,98 & 258,93 \\
\hline $\begin{array}{c}\text { Classe E - } \\
20 h\end{array}$ & 121,99 & 48,79 & 170,78 & 199,81 & 79,92 & 279,73 \\
\hline $\begin{array}{c}\text { Classe F - } \\
20 h\end{array}$ & 134,47 & 53,78 & 188,25 & 212,29 & 84,92 & 297,21 \\
\hline $\begin{array}{c}\text { Classe G - } \\
20 h\end{array}$ & 150,23 & 60,19 & 210,32 & 228,05 & 91,22 & 319,27 \\
\hline $\begin{array}{c}\text { Classe H - } \\
20 h\end{array}$ & 166,67 & 60,66 & 233,33 & 244,49 & 97,80 & 342,29 \\
\hline $\begin{array}{c}\mathbf{4 0} \\
\text { HORAS }\end{array}$ & Vcto & Regência & Total & Vcto & Regência & Total \\
\hline $\begin{array}{c}\text { Classe A - } \\
40 h\end{array}$ & 204,36 & 81,74 & 286,10 & 282,18 & 122,87 & 395,05 \\
\hline $\begin{array}{c}\text { Classe B - } \\
40 h\end{array}$ & 207,67 & 83,06 & 209,73 & 285,48 & 114,19 & 399,67 \\
\hline $\begin{array}{c}\text { Classe C - } \\
40 h\end{array}$ & 210,00 & 84,38 & 295,35 & 288,78 & 115,51 & 404,29 \\
\hline \hline
\end{tabular}

19 Núcleo composto por professores do Centro de Ciências da Educação (CCE), do Centro de Ciências Humanas e Letras (CCHL), da Universidade Federal do Piauí, por membros do SINTE-PI e integrantes do Centro Piauiense de Ação Cultural (CEPPC). 


\begin{tabular}{||c|c|c|c|c|c|c||}
\hline $\begin{array}{c}\text { Classe D - } \\
40 h\end{array}$ & 214,26 & 85,70 & 299,96 & 292,08 & 116,83 & 408,91 \\
\hline $\begin{array}{c}\text { Classe E - } \\
40 h\end{array}$ & 253,98 & 101,59 & 355,57 & 321,80 & 128,72 & 450,52 \\
\hline $\begin{array}{c}\text { Classe F - } \\
40 h\end{array}$ & 278,92 & 111,56 & 390,48 & 346,76 & 138,70 & 485,46 \\
\hline $\begin{array}{c}\text { Classe G - } \\
40 h\end{array}$ & 308,48 & 123,39 & 431,87 & 378,28 & 151,31 & 529,59 \\
\hline $\begin{array}{c}\text { Classe H - } \\
40 h\end{array}$ & 333,34 & 133,33 & 466,67 & 411,16 & 164,46 & 575,62 \\
\hline
\end{tabular}

Quadro 5: Salários dos Professores de 20h e 40h Semanais em Início de Carreira $^{20}$

Embora seja perceptível uma mudança mais significativa que a exposta no Relatório do TCE-PI, é importante observar que esses dados se referem a um período maior que o analisado pelo Tribunal. Sendo assim, esses dados reforçam a idéia já exposta pelo Relatório de que os professores da rede pública estadual, independente da etapa da Educação Básica em que trabalhavam, não tiveram melhorias expressivas em seu salário. As variações observadas ocorreram em função da própria mudança do poder aquisitivo da moeda brasileira e não por conta de melhoria salarial. Para se fazer uma comparação entre salários desse período, utilizamos como referencial o salário mínimo vigente no País. No ano de 1995, o salário mínimo era de $R \$ 70,00$ e, em 2001, era de $R \$ 180,00$, o que faz com que percebamos que não houve melhoria significativa na remuneração do magistério público estadual. Isso ainda era agravado, segundo os Relatórios do TCE-PI, pelos constantes atrasos no pagamento de salários, ou seja:

O objetivo primordial do FUNDEF é a valorização do magistério, visando, basicamente, melhorias salariais. Mesmo assim, a situação dos professores do ensino fundamental da SEED permanece a mesma da época anterior ao FUNDEF, com o agravante de continuarem com os salários atrasados, embora os recursos do FUNDO sejam creditados regularmente nas contas específicas (PIAUÍ, TCE, 2000, p.14-15).

${ }^{20}$ Fonte: DRH/SEDUC. In: BRASIL. Universidade Federal do Piauí, 2002. 
Essa condição foi mencionada tanto no Relatório publicado em 24 de maio de 2000 , quanto no do dia $1^{\circ}$ de dezembro de 1999 , o que evidenciou que o atraso de salários dos professores não era um fato esporádico.

\section{Considerações Finais}

Mesmo tendo havido pouco impacto do FUNDEF na remuneração do magistério da rede oficial do Piauí, assim como se tem apontado, e tenham existido dificuldades nos registros e controle em relação a quem tem cursado licenciaturas financiadas com recursos desse Fundo, observamos que vários professores passaram a ter possibilidade de se qualificar. Essa tem sido uma das principais contribuições do FUNDEF para a educação piauiense. A outra foi o papel desempenhado pelo Fundo na ampliação da preocupação do Poder Público com a matrícula e a permanência dos alunos nas escolas estaduais.

Tudo isso associado, evidencia também que o FUNDEF contribuiu apenas parcialmente para a valorização do magistério, uma vez que ele não repercutiu no item melhoria salarial, não evitando as greves e paralisações dessa categoria, mas atuou na qualificação de parcela dos professores da rede pública estadual, assim como também contribuiu parcialmente para a melhoria do atendimento ao aluno, pois mesmo sendo voltado para o Ensino Fundamental, inspirou pressões sociais sobre o Executivo Estadual visando à ampliação da oferta de vagas no Ensino Médio. Mesmo assim, a conclusão que se pode chegar quanto ao período analisado é que a preocupação do governo se tinha restringido ao item matrícula, voltando-se mais para o repasse de verbas, e pouco com a eficiência da escola oferecida à sociedade.

Os docentes pesquisados foram unânimes em afirmar que a situação salarial foi a pior dificuldade enfrentada pela categoria, limitando muito de seu desempenho profissional, e enfatizaram que o FUNDEF não alterou tal situação, a não ser o item qualificação profissional, já discutido. 
A situação salarial continuava incomodando os professores durante o período analisado, sem, contudo, ser a única. Os docentes frisaram que a carência de recursos didáticos para ministrarem boas aulas e a excessiva pressão, promovida pelo Poder Público para aprovação dos alunos são outras dificuldades enfrentadas no período. Nos depoimentos, os professores se referiram à primeira como algo que já estaria atrelado ao próprio ensino público, naturalizando uma construção social; quanto à segunda dificuldade, demonstraram surpresa quanto a esse posicionamento, que consideram ter-se manifestado mais a partir do final da década de 1990, mas apenas oito professores associaram isso ao fato de repasse de verbas, 21 disseram que isso fazia parte das intenções governamentais em sucatear mais o ensino público e 14 preferiram não ter opinião formada a respeito.

Isso revela como professores da rede pública estadual se sentiam aviltados em seus salários e nas condições de trabalho e, além de tudo isso, ainda se consideravam desrespeitados nas ações avaliativas feitas pelos discentes. Essa realidade ficou bastante evidente em um comentário, mais um desabafo, constante do final do questionário de um dos professores pesquisados:

\footnotetext{
"Além de ser desrespeitado no bolso, o professor no Piauí ainda não é respeitado na escola, nem fora dela (...) mas também o que era de se esperar, se nós nem podemos mandar dentro da sala de aula, nem mesmo ao avaliar assuntos que nós preparamos para ensinar? (...) Só fica quem não tem outra alternativa, é uma pena."
}

Essa visão pessimista a respeito da desvalorização ao docente foi uma marca da fala de todos os professores pesquisados e demonstra que, além de baixa remuneração, os professores estão em verdadeiro dilema em relação às orientações governamentais acerca dos índices de alunos a serem aprovados. Isso prejudica bastante a qualidade do aprendizado, segundo os professores, pois os alunos percebem que os critérios são bastante flexíveis e maleáveis e não se esforçam o suficiente. 
Quanto ao critério qualidade de ensino, os pais pesquisados afirmaram que houve uma inversão proporcional à regularidade do atendimento, que passou a ser mais frequente, enquanto a qualidade teria sido reduzida. Essa insatisfação dos pais também foi constatada, em pesquisa recente a respeito da implantação do FUNDEF em Teresina:

Os Pais também revelaram uma grande preocupação a respeito da implantação das circunstâncias em que seus filhos são aprovados, afirmando haver casos de alunos que não dominam os conteúdos da série em que estão e são aprovados (SOUSA NETO, 2003, p. 131).

É muito precoce uma avaliação mais detalhada a respeito dos aspectos atendimento ao aluno e valorização do magistério, uma vez que o período analisado é muito curto, isto é, apenas três anos após a implantação do FUNDEF, o que induz a concordar com a análise afirmando que,

\begin{abstract}
Malgrado tais percalços, vale salientar que o processo de discussão desencadeado nos Estados e Municípios, pela instituição do mencionado fundo, tem aprofundado o relacionamento entre Estado e Municípios, a redefinição ou reafirmação de responsabilidades e a divisão de tarefas entre essas instâncias, bem como a definição de formas concretas de colaboração. Tem, também, ensejado um maior relacionamento com universalidades e faculdades de formação de professores instadas que estão a responder a curto prazo estipulado pela lei n. $9.424 / 96$ pela formação de professores leigos, mas diferentes acepções que a expressão envolve (WEBER, 1998, 1998, p. 8).
\end{abstract}

Dessa forma, não se pode perder a perspectiva de que "avanços sociais pressupõe conflitos, mas também negociação e acordos, mesmo que alguns desses sejam apenas circunstanciais e, portanto, temporários" (WEBER, 1998 , p. 12) e cabe à sociedade criar espaços para que mais negociações sejam realizadas, visando ampliar as conquistas sociais. 


\section{Referências bibliográficas}

ARRETCHE, M. Estado Federativo e Políticas Sociais. Revan, 2000.

BOAKARI, F. M.; ROCHA, R. M. G. A educação no Piauí. Brasília: UNICEF, MEC/Fundescola, Banco Mundial/UNDIME, 1999.

BOBBIO, N. Estado, governo, sociedade: para uma teoria geral da política. 4 ed. Trad. Marco Aurélio Nogueira. Rio de Janeiro: Paz \& Terra, 1999.

BRASIL. Lei no 9.424, de 24 de dezembro de 1996. Fundo de Manutenção e de Desenvolvimento do Ensino Fundamental e de Valorização do Magistério. Brasília/DF: MEC, 1996.

BRASIL. Emenda Constitucional n. 14, de 12 de setembro, publicada no DOU em 13/09, 1996.

BRASIL. Lei no 9.394, de 20 de dezembro de 1996. - Lei de Diretrizes e Bases da Educação Nacional. Brasília/DF: MEC, 1996.

BRASIL. Constituição da República Federativa do Brasil: promulgada em 5 de outubro de 1988. 21 ed. São Paulo: Saraiva, 1999.

BRASIL. MEC. Balanço do primeiro ano do Fundef. Brasília: MEC, 1999.

BRASIL. UNIVERSIDADE FEDERAL DO PIAUÍ. Relatório de pesquisa: o processo de implantação e o impacto do FUNDEF no Piauí (1998-2000). Teresina-PI: UFPI/CCE, 2002.

CARNOY, M. Estado e teoria política. Tradução: Equipe de Tradutores do Instituto de Letras da Unicamp. 3 ed., Campinas: Papirus, 2001.

COSTA, T. Os anos noventa: o ocaso do político e a sacralização do mercado. In: MOTA, C. G. (Org.). Viagem Incompleta: A Experiência Brasileira. São Paulo: SENAC, 2000.

CNTE. São Paulo, 2 a 9 abr. 2001.

DAVIES, N. O FUNDEF e o orçamento da educação: desvendando a caixa preta. Campinas, SP: Autores Associados. (Coleção polêmicas de nosso tempo; 64). 1999.

FONTINELES, C. C. da S. Do Ocaso Aparente ao Aparente Investimento: a situação do magistério e do atendimento ao aluno na história recente da rede estadual de ensino do Piauí (1988-2000). Teresina: UFPI (Dissertação de Mestrado em Educação), 2003.

GADOTTI, M. 2000. O Projeto da Escola Cidadã. In: Perspectivas Atuais da Educação. Porto Alegre: Artmed, 1999.

O Globo. Rio de Janeiro, 4 abr. 1999.

PIAUÍ. Mensagem do Governador do Estado à Assembléia Legislativa 1995. Teresina, fevereiro, 1995. 
PIAUÍ, TCE. Relatório de prestação de contas da Secretaria Estadual de Educação do Piauí, exercício 1998. Teresina: Tribunal de Contas do Estado do Piauí, 2000.

PIAUÍ, TCE. Relatório de prestação de contas da Secretaria Estadual de Educação do Piauí, exercício 1999. Teresina: Tribunal de Contas do Estado do Piauí, 2000.

PINTO, J. M. R. Um fundinho chamado "fundão". In: DOURADO, L. F. (Org.). Financiamento da educação básica. Campinas SP: Autores Associados, 1999.

SAVIANI, D. O debate teórico e metodológico no campo da história e sua importância para a pesquisa educacional. In: SAVIANI, D.; LOMBARDI, J. C.; SANFELICE, J. L. (Org.). História da educação: perspectivas para um intercâmbio internacional. Campinas: Autores Associados/HISTEDBR, 1998.

SHIROMA, E. O. et all. Política educacional. Rio de Janeiro: DP\&A, 2002.

SINTE-PI. Histórico e organização das instâncias democráticas do SINTE-PI e concepção, estrutura e prática sindical. Teresina: SINTE-PI, fev, 2000.

SOUSA NETO, M. de. O impacto do FUNDEF no atendimento ao aluno do ensino fundamental da rede estadual de educação em Teresina (19962002): conquistas, limites e potencialidades. Teresina: UFPI (Dissertação de Mestrado em Educação), 2003.

WEBER, S. Novos Padrões de financiamento e impactos na democratização do ensino. Cadernos de Pesquisa, n. 103, mar/1998. p. 5-13. São Paulo: Fundação Carlos Chagas/ Cortez, 1998.

\section{Referências Hemerográficas:}

Meio Norte. Teresina, 28 mar. 1995.

O Dia. Teresina, 16 Maio 1995.

O Dia. Teresina, 6 Ago. 1996.

O Dia. Teresina, 14 Ago. 1996.

O Dia. Teresina, 22 Ago. 1996.

O Dia. Teresina, 26 Set. 1996.

O Dia. Teresina, 5 Fev. 1997.

Recebido em 04 de junho de 2012. Aprovado em 05 de outubro de 2012. 